ИЗВЕСТИЯ АКАДЕМИИ НАУК ЭСТОНСКОИ ССР. ТОМ ХV СЕРИЯ ФИЗИКО-МАТЕМАТИЧЕСКИХ И ТЕХНИЧЕСКИХ НАУК. 1966, № 1

\title{
ОСНОВНЫЕ ЧЕРТЫ ГЕОЛОГИЧЕСКОГО РАЗВИТИЯ ЗАПАДНОЙ ЛАТВИИ В РАННЕМ ПАЛЕОЗОЕ
}

За последние годы на территории Западной Латвии пробурен ряд структурных скважин, впервые вскрывших полные разрезы нижнего палесзоя. Эти разрезы, наряду с новыми геофизическими данными, коренным образом изменили прежние представления о тектонической структуре и геологическом развитии рассматриваемой территории. Так, на структурных и палеотектонических схемах, опубликованных еще в 19591962 гг. $\left[{ }^{1-3}\right]$, рисуется общее пологое погружение фундамента через зону перехода южного склона Балтийского щита в Балтийскую синеклизу. Предполагалссь, что в этом районе отложения нижнего кембрия и тремадока отсутствуют. Структурные же построения, сделанные А. Файтельсоном в 1958-1962 гг. [4, 5] на основании геофизических исследований и подтвердившиеся последующим бурением, сводятся к наличию в додевонском структурном этаже на рассматриваемой территории трех резко различных элементов - Рижской впадины на севере, Лиепайско-Елгавского выступа в середиш и Куршской впадины на юге.

Большое значение для палеогеографии имеет впервые обнаруженное по материалам Западной Латвии распространение в ордовике средней Прибалтики литофаций и фаун среднешведского типа $\left[{ }^{6}, 7\right]$.

Опираясь, главным образом, на результаты обработки кернового материала пяти структурных скважин (Пилтене, Ремте, Блидене, Стури и Адзе), автор в данной: статье кратко останавливается на раннепалеозойской истории геологического развития западной части территории Латвийской ССР.

\section{Докембрийский и кембрийский периоды}

Валдайская эпоха (рис. 1a). Наличие валдайских отложений в Пилтенской скважине и их отсутствие в южной части изученной территории (в скважинах Адзе, Ремте, Блидене и Стури) позволяет предполагать, что осадконакопление в валдайскую эпоху было приурочено только к северной части Курземского полуострова, которая представляла собой небольшую впадину. Низы валдайской серии (гдовской свиты) представлены красноватыми грубозернистыми песчаниками с косой слоистостью, что указывает, вероятно, на их формирование в континентальных условиях, впоследствии сменившихся морскими. Накопление нижневалдайских песчаников сопровождалось частыми колебательными движениями, о чем свидетельствует чередование прослоев гравелитов с более гонким материалом, а также наличие прослоев охристо-желтых алевритистых глин. В конце ранневалдайского времени наступил кратковременный перерыв в осадконакоплении, причем верхняя часть этих отложений подвергалась выветриванию. Об этом свидетельствуют прослои ленточных глин охристо-желтого цвета. Трансгрессия поздневалдайского моря 
вновь заняла северную часть Курземского полуострова. Здесь, так же как и в ранневалдайское время, отлагались песчаники. Вся остальная территория Западной Латвии в валдайское время была приподнятой (рис. $1 a$ и $4 a$ ).

К концу валдайской эпохи происходит региональное поднятие всей территории и здесь устанавливается континентальный режим. Подтверждением этого служит размыв верхневалдайских слоев в скважине Пилтене, где сохранилась только их базальная часть. Максимальная мощность валдайского комплекса, а следовательно и величина соответствующего прогибания земной коры, составляет около $40 \mathrm{M}$.

Балтийская эпоха (рис. 16, 1в). Балтийская серия представлена в Западной Латвии в нижней своей половине белыми кварцевыми песчаниками, которые развиты только в северной части территории, а в. верхней половине - алевритистыми глинами и глинистыми алевролитами, развитыми на всей рассматриваемой территории.
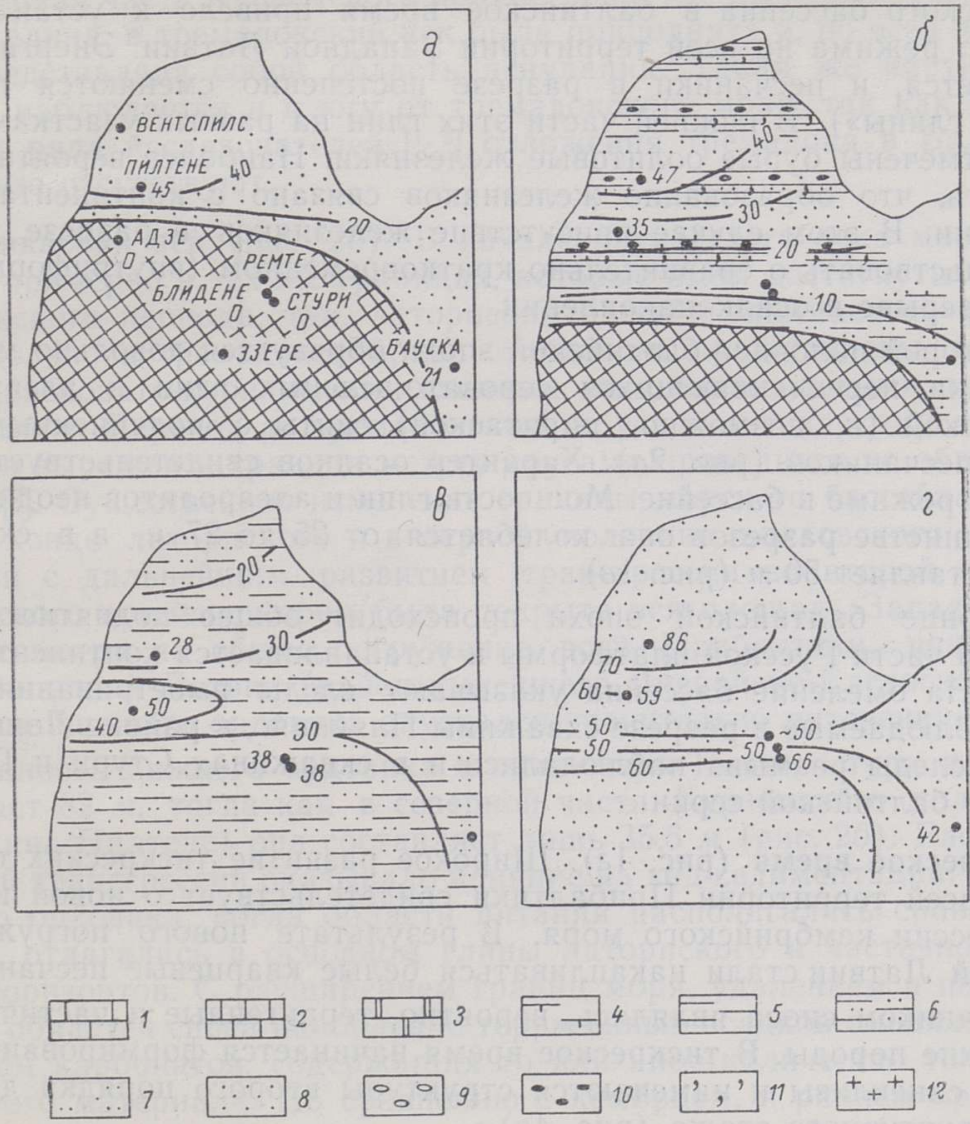

Рис. 1. Распределение фаций кембрийских отложений в Западной Латвии: $a$ - валдайская эпоха; $\sigma$ - раннебалтийское время; в - позднебалтийское время; 2 - тискреское время. Типы пород на рис. $1-4: 1$ - известняки, 2 - афанитовые известняки, 3 - доломиты, 4 - мергели, 5 - глины, 6 - алевритистые глины, 7 алевриты, 8 - песчаники, 9 - известковые оолиты, 10 - железистые оолиты, 11 - глауконит, 12 - кристаллический фундамент. Районы отсутствия отложений указаны перекрестной штриховкой. 
Начало балтийской эпохи в Западной Латвии ознаменовалось новым погружением северной части Курземского полуострова и развитием новой морской трансгрессии. Границы морского бассейна совпадали с границами. предыдущего, валдайского моря. Южная часть Западной Латвии все еще осталась приподнятой и являлась областью сноса. Отлагались крупнозернистые кварцево-глауконитовые песчаники, но по мере пенепленизации значительно ослабла энергия сноса и в морской бассейн стал поступать более тонкий материал (рис. 1б). Формирование отложений ломоносовской свиты происходило в условиях постепенной стабилизации тектонического режима.

В начале формирования лонтоваской свиты происходит изменение тектонического режима: южная часть территории и Балтийский щит, по-видимому, испытывают некоторое поднятие, что приводит к интенсивной эрозии в областях сноса. Следствием этих изменений является накопление белых кварцевых песчаников, мощность которых в скважине Пилтене достигает 3,0 м.

По мере пенепленизации окружающих массивов дальнейшее развитие морского бассейна в балтийское время привело к установлению морского режима на всей территории Западной Латвии. Энергия сноса ослабляется, и песчаники в разрезе постепенно сменяются глинами («синие глины»). В нижней части этих глин на разных участках территории отмечены бурые оолитовые железняки. Наиболее вероятно предположить, что образование железняков связано с континентальнымі условиями. В этом случае присутствие железняков в разрезе должно свидетельствовать о сравнительно кратковременном (внутриформационном) перерыве в осадконакоплении.

Во второй половине балтийской эпохи образуется довольно монотонная пачка переслаивающихся серовато-зеленых глин и алевролитов лонтоваской (и, возможно, пиритаской) свиты с подчиненными прослоями песчаников (рис. 2в). Характер осадков свидетельствует о стабильном режиме в бассейне. Мощность глин и алевролитов неодинакова. В большинстве разрезов она колеблется от 25 до $27 \mu$, а в скважине Адзе составляет $50 \mu$ (рис. 1в).

В конце балтийской эпохи происходит общее поднятие северозападной части Русской платформы и устанавливается континентальный режим. На омеление бассейна указывают следы выветривания синих глин, наблюдаемые в разрезе скважины Плявиняс, в районе Локно и др. Слабые следы размыва наблюдались и в скважинах Стури и Пилтене в верхах балтийской серии.

Тискреское время (рис. 12). Широкое развитие тискреских отложений на всей территории Прибалтики свидетельствует о новой крупной трансгрессии кембрийского моря. В результате нового погружения в Западной Латвии стали накапливаться белые кварцевые песчаники.

Источником сноса являлись, вероятно, терригенные -и частично магматические породы. В тискреское время начинается формирование Балтийской синеклизы и намечаются структуры второго порядка додевонского структурного этажа (рис. $4 a$ ).

Распределение мощностей тискреских отложений, изображенное на рис. 12, указывает на резко выраженные зоны прогибания. Одна из них обособляется в северной части Курземского полуострова и является прообразом Рижской впадины. Вторая расположена на территории Литвы (Куршская впадина).

Северная и южная зоны прогиба отделяются друг от друга четко выраженным поднятием - Лиепайско-Елгавским валом, который характе- 
ризуется сокращенной мощностью тискреских отложений (48 $м$ в скважине Ремте). К северу и югу от Лиепайско-Елгавского вала наблюдается постепенное нарастание мощностей, достигающих максимума в Рижской впадине ( 86 м в скважине Пилтене).

\section{Ордовикский период}

Тремадокский век (рис. $2 a$ ). На границе кембрия и ордовика происходит изменение структурного плана западной части Латвии. В начале ордовика прогибание земной коры происходило в центральной части Западной Латвии по линии Ли́епая-Елгава, т. е. на месте ныне существующего Лиепайско-Елгавского вала. В этот узкий прогиб с запада трансгрессировало тремадокское море. В этом прогибе отлагались оболовые конгломераты, глауконитовые песчаники, глины пакерортского горизонта и цератопигевых слоев.

Северная часть Курземского полуострова, где ныне выделяется Рижская впадина, в тремадокский век была приподнята и, по всей вероятности, представляла собой область денудации. Такая же картина, возможно, наблюдается и к югу от тремадокского моря, так как согласно данным ряда исследователей $[1,8]$ отложения тремадока в Балтийской синеклизе отсутствуют.

Онтикаский век (рис. 2б). В начале онтикаского века море сохраняется примерно в тех же границах, которые были достигнуты в начале ордовикского периода; так, латорпский бассейн занимает почти ту же площадь, что и тремадокский, его отложения представлены аналогичными красновато-коричневыми глинами, но с более частыми прослоями известняков. Переход от тремадокского яруса к онтикаскому литологически не выражен и граница между ярусами проводится по обновлению фауны [7]. Существенное изменение границы морского бассейна произошло в конце латорпского и в первой половине волховского времени. В связи с дальнейним развитием трансгрессии во второй половине латорпского времени морем была покрыта вся площадь Западной Латвии. Несмотря на общее погружение всей Прибалтики, центральная часть Западной Латвии (район нынешнего Лиепайско-Елгавского вала) в течение нижнего ордовика опускался значительно интенсивнее.

Мощность нижнего ордовика в скважинах Ремте, Стури и Блидене достигает 82 , тогда как в северной части Курземского полуострова (скважина Пилтене) она составляет лишь 35,5 м (рис. 26). Расширение морской трансгрессии оказывало влияние на ход седиментации. В начале раннего ордовика, когда области питания располагались сравнительно близко, отлагались в основном глины латорпского и частично волхов ского горизонтов. С расширением границ моря, удалением и пенепленизацией областей сноса накопление терригенных осадков сменилось образованием карбонатов, содержащих то или иное количество тонкого обломочного материала. По сравнению с кембрием, в раннем ордовике в бассейне распространилась новая богатая по составу фауна трилобитов, брахиопод и головоногих, хорошо характеризующая отдельные горизонты и подгоризонты [7].

Пуртсеский век (рис. 2в). В среднем ордовике выделяются два этапа развития территории: пуртсеский и курнаский века. В эти века продолжалось развитие тех же структурных элементов, которые были зало. жены в раннем ордовике. Пуртсеский век характеризуется непрерыв- 

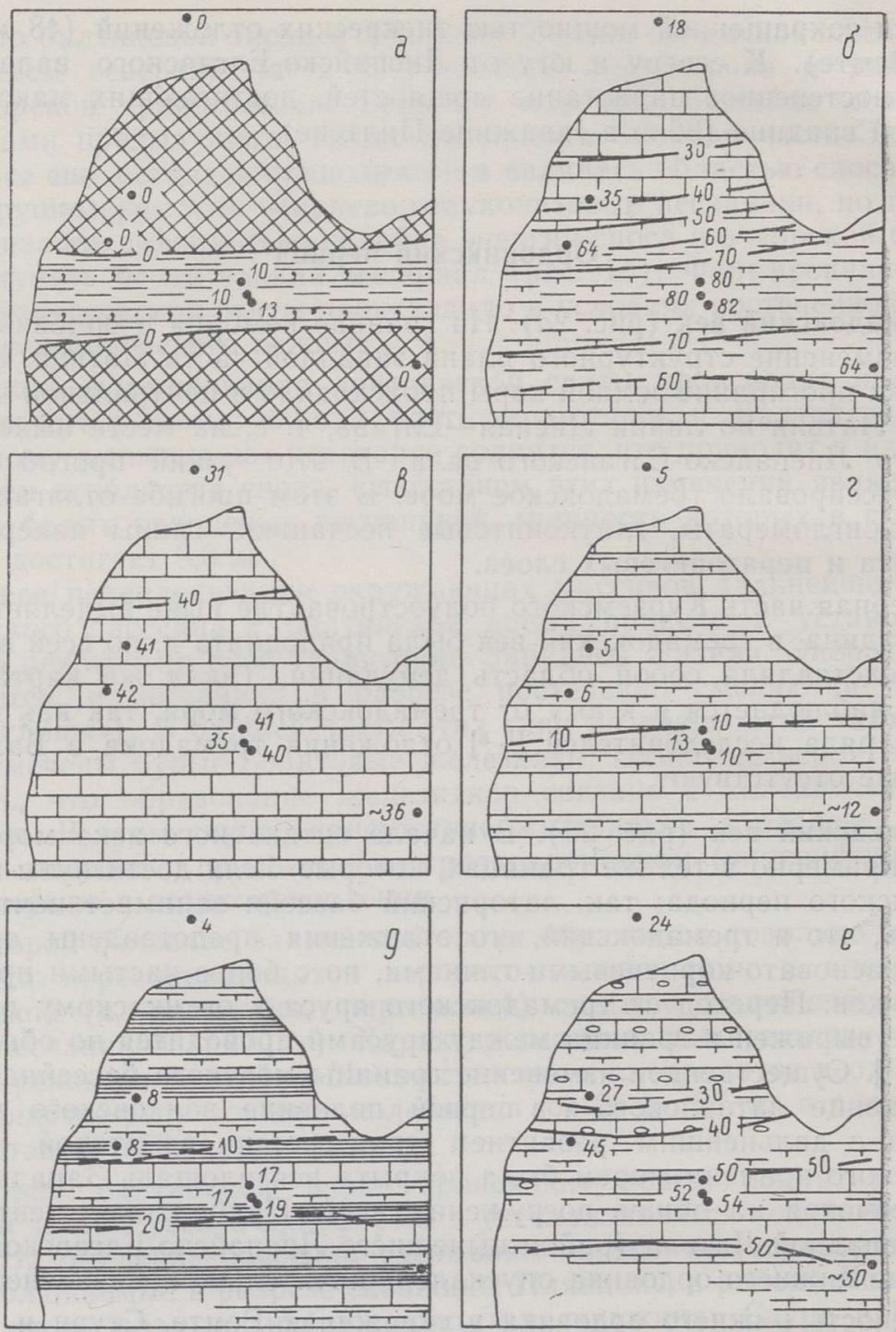

Рис. 2. Распределение фаций ордовикских отложений в Западной Латвии: $a$ - тремадокский век; 6 - онтикаский век; впуртсеский век; 2 - курнаский век; д - плюсский век; $e$ - ашгилльский вск.

ным накоплением карбонатных отложений, мощность которых на территории Западной Латвии примерно одинакова (35-41 м). Этот факт свидетельствует о равномерном прогибании всей рассматриваемой өбласти.

Курнаский век (рис. 22). Во второй половине среднеордовикской эпохи, т. е. в курнаский век, вновь наблюдается некоторое погружение центральной части Западной Латвии и, в связи с этим, увеличение мощности отложений. В это время, в связи с оживлением вулканической деятельности в Каледонской геосинклинали, на северо-западе Русской платформы отлагался вулканический материал в виде тонких слоев метабентонитовых глин. Увеличение прослоев мергелей и значителыная гли- 
нистость известняков курнаского яруса свидетельствует о возросшем привносе тонкого глинистого материала.

В конце курнаского века в бассейне возникли застойные условия, приведшие к образованию черных битуминозных аргиллитов. В последних отмечена повышенная концентрация никеля, молибдена, вольфрама и ванадия.

Плюсский век (рис. 22). В первой половине плюсского века (в набалаское время) в Западной Латвии имели место повторные кратковременные изменения режима осадконакопления, что отражается в переслаивании мергелей и афанитовых известняков. В конце века бассейн снова приобретает застойный характер, и в нем отлагаются черные битуминозные аргиллиты. В плюсском веке происходит и обновление фауны.

Ашгилльский век (рис. $2 e$ ). В ашгилльский век центральная часть Заіадной Латвии (на месте ныне существующего Лиепайско-Елгавского вала) по-прежнему остается областью, где накапливались наиболее мощные осадки. Центр максимального прогибания располагался в районе скважины Стури $(54$ м). Сокращение моњности происходило в северном направлении - в скважине Пилтене она достигает 27 м (рис. 4б). В начале века на всей территории отлагались красновато-коричневые мергели с прослоями известняков. Повышение привноса терригенного материала, возможно, связано с обновлением источников сноса. В конце ашгилльского века, видимо, происходило новое погружение Западной Латвии и сглаживание рельефа питающих областей. Границы бассейна расширялись, хотя он по-прежнему оставался мелководным. В этом бассейне отлагались афанитовые известняки с комковатой текстурой.

Афанитовые известняки развиты в основном только в центральной части Западной Латвии. В северной части, как это показано на палеогеографической схеме (рис. $2 e$ ), они замещаются оолитовыми известняками верхов ашгилльского яруса, свидетельствующими о частых колебательных движениях в бассейне осадконакопления.

\section{Силурийский период}

Лландоверийский век (рис. $3 a$ ). Переход от ордовика к силуру не вызвал на рассматриваемой территории изменений в процессе осадконакопления, вследствие чего ашгилльский и лландоверийский века составляют здесь единый этап геологического развития. В лландоверийский век характер изменения мощностей остается примерно таким же, как іғ в ашгилльском. Уменьшение мощности наблюдается к северу и югу. План распределения фаций также не претерпевает существенных изменений. В раннелландоверийском море продолжалось образование светло-серых афанитовых известняков с брекчиевидной текстурой, что указывает на мелководье с сильными донными течениями.

В среднелландоверийское время бассейн принимает застойный характер. В условиях спокойной среды этого относительно глубокого бассейна, в котором отсутствовали волнения и сильные течения, происходило накопление темно-серых до почти черных граптолитовых сланцев.

В позднем лландовери условия осадконакопления не изменились, только вместо глин в бассейне накапливались серые и зеленовато-серые мергели с фауной граптолитов. 

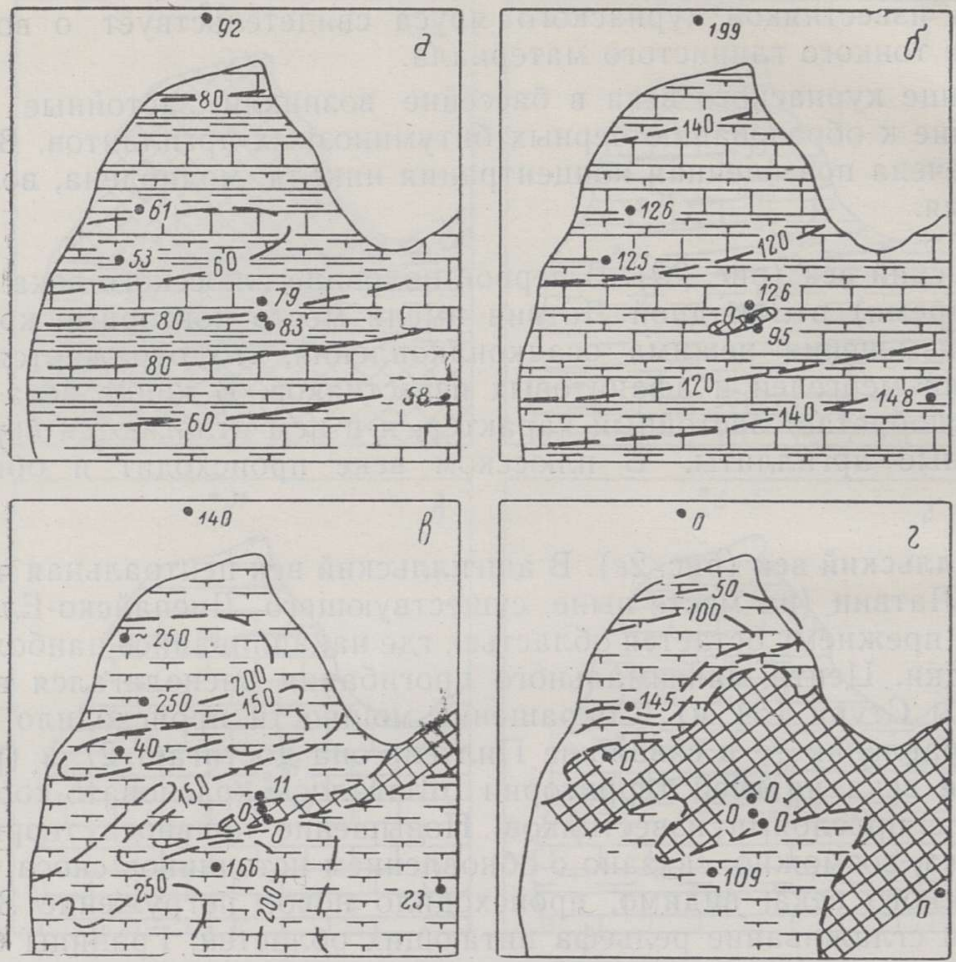

Рис. 3. Распределение фаций силурийских отложений в Западной Латвии: $a$ - лландоверийский век; $\sigma$ - венлокский век; в - раннелудловский век; 2 - позднелудловский век.

Венлокский век (рис. 3б). В венлокском веке характер осадконакопления по сравнению с лландоверийским не изменился. Накапливались сравнительно мощные толщи сильно глинистых мергелей, которые без каких-либо признаков перерыва или изменения условий седиментации залегают на лландоверийских отложениях (рис. 4б). Цвет мергелей серый и зеленовато-серый. Застойный характер бассейна оказался благоприятным для повышенного скопления органических остатков.

Вверх по разрезу известковистые мергели сменяются доломитовыми. Появление доломитизации, видимо, свидетельствует о повышении солености морской воды.

Раннелудловский век (рис. 3в). В раннелудловском веке начинается перестройка структурного плана Западной Латвии, обусловленная поднятием в центральной части этой территории. Лиепайско-Елгавская зона, которая на протяжении всего ордовика и нижнего силура была максимально прогнута, по-видимому, вновь начала постепенно подниматься. В описываемый век продолжалось также поднятие фундамента южного склона Балтийского щита и Латвийской седловины, тогда как в центральных частях Рижской и Куршской впадин происходило интенсивное прогибание. Это подтверждается распределением мощностей нижнелудловского яруса, максимальная мощность которого составляет 250 м (рис. 4в). Возможно, что Лиепайско-Елгавская зона вследствие интенсивных восходящих движений была приподнята выше уровня моря, так как в этой зоне лудловские отложения отсутствуют. Однако 

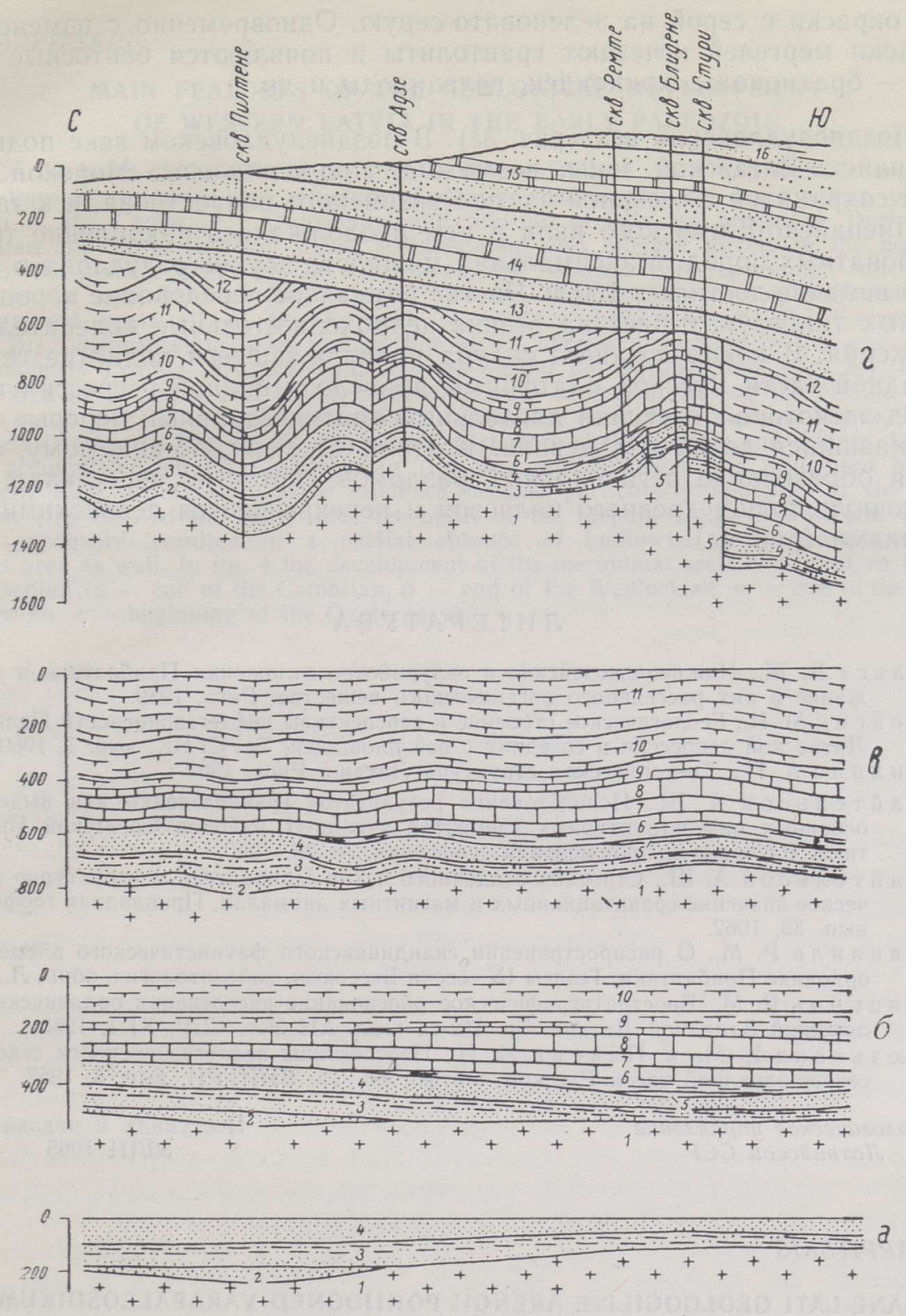

Рис. 4. Геологический разрез нижнепалеозойских отложений в Западной Латвии: $a$ - конец кембрийского периода, 6 - конец венлокского века, в - конец раннелудловского века, 2 - начало четвертичного периода; 1 - кристаллический фундамент, 2 - валдайская серия, 3 - балтийская серия, 4 - тискреская свита, 5 - тремадокский ярус, 6 - онтикаский ярус, 7 - средний ордовик, 8 - верхний ордовик, 9 - лландоверийский ярус, 10 - венлокский ярус, 11 нижнелудловский ярус, 12 - верхнелудловский ярус, $13-$ нижний девон, 14 - средний девон, 15 - верхний девон, 16 - нижний карбон.

не исключена также возможность, что отложения были уничтожены по следующей денудацией в самом конце силура.

В начале раннелудловского времени продолжалось отложение серых глинистых мергелей. Вверх по разрезу постепенно происходит измене- 
ние окраски с серой на зеленовато-серую. Одновременно с изменением окраски мергелей исчезают граптолиты и появляются бентосные формы - брахиоподы, криноидеи, пелециподы и др.

Позднелудловский век (рис. 32). В позднелудловском веке поднятие Лиепайско-Елгавской зоны, возможно, продолжалось. Морской бассейн сохранялся в северной части Курземского полуострова, и к западу от Лиепайско-Елгавского вала в нем продолжалось накопление толщи карбонатных пород. Максимальная мощность верхнего лудлова в Рижской впадине достигает $100 \mu$. Частое ритмичное чередование пород различных типов указывает на резкие непродолжительные колебательные движения. В конце позднего силура продолжавшееся поднятие северозападной части Русской платформы привело к полной регрессии моря, вслед за которой наступил длительный континентальный перерыв, продолжавшийся до начала девона. К этому времени, по-видимому, относится образование региональных разломов, которые пересекают всю осадочную толщу древнего палеозоя и перекрываются девонскими песчаниками (рис. 4c).

\section{ЛИТЕ РА Т У Р А}

1. У льст Р. Ж., Нижнепалеозойские и силурийские отложения Прибалтики: и содержание в них рассеянного органического вещества, Рига, 1959.

2. П е й с и к М. И., Геологическое строение и перспективы нефтегазоносности ПольскоЛитовской депрессии и соседних с ней площадей, Тр. СГПК, вып. 1, 1960.

3. И п д а н с А. П., Тектоническая структура Латвии, Рига, 1962.

4. Ф а йтельсон А. Ш., Использование результатов гравиразведки для выделения основных палеоструктурных элементов западных районов Советской Прибалтики, Разведка и промысловая геофизика, № 36, 1960.

5. Ф а йт ел ьсон А. Ш., Строение осадочного чехла Прибалтики и структурно-техническое значение гравитационных и магнитных аномалий, ПІрикладная геофизика, вып. 35, 1962

6. Мяннниль Р. М., О распространении скандинавского фаунистического элемента в ордовике Прибалтики, Тезисы IX сессии Всесоюзн. палеонтологич. общ., Л., 1963.

7. Мяннн и л Р. М., Биостратиграфическое обоснование расчленения ордовикских отложений Западной Латвии, Тр. Ин-та геол. АН Эст. ССР, XIII, 1963.

8. Л ютке вич Е. М. и Пей с ик М. И., Перспективы нефтегазоносности северо- и северо-западной чаети Русской платформы, Тр. ВНИГРИ, вып. 3, 1957.

Геологическое управление Латвийской ССР
Поступила в редакцию $30 /$ III 1965

\section{KARPITSKIS}

\section{LÄANE-LÄTI GEOLOOGILISE ARENGU PÕHIJOONED VARAPALEOSOIKUMIS}

Tuginedes Piltene, Remte, Blidene, Sturi ja Adze puuraugu andmetele, esitatakse Lääne-Läti geoloogilise ehituse ning àrengu põhijooned kambriumi, ordoviitsiumi ja siluri vältel. Valdai ja varabalti ajal toimus settimine ainult antud piirkonna põhjaosas (joon. $1 a, \sigma)$, kuna selle lōunaosa kujutas endast maismaad. Hilisbalti (joon. 18), samuti tiskre eal (joon. 12) haaras epikontinentaalne meri enda alla kogu Lääne-Läti. Tremadokis (joon. $2 a$ ) piirdus settimine ainult praeguse Liepaja-Jelgava valli kohal asetsenud kitsa nōoga, kuna ontika ajajärgul (joon. 26) kuhjusid samas savikamad ja suurema paksusega setted. Keskordoviitsiumis (joon. 26, 2) valitsesid kogu Lääne-Läti alal ühtlased tingimused, kuna hilisordoviitsiumis (joon. $2 \partial$, e) kuhjusid põhjas rannalähedasemad ja väiksema paksusega setted. Ländouveris (joon. $3 a$ ) hakkas settimist mõjustama põhjapoolne, Riia nõgu, mille olemasolu eriti selgesti ilmnes uenlokis (joon. 3б). Samal ajal algas Liepaja-Jelgava valli kerkimine, mis nähtavasti on põhjustanud ka siin ladlou setete osalise puudumise (joon. $3 \varepsilon$, c). Joonisel 4 on esitatud Lääne-Läti meridionaalse geoloogilise läbilōike kujunemine üksikute arenguetappide kaupa ( $a$ - kambriumi lõpp, б - uenloki lõpp, в - varaladlou lõpp, z - kvaternaari algus). 


\section{KARPITSKIS}

\section{MAIN FEATURES OF THE GEOLOGICAL DEVELOPMENT OF WESTERN LATVIA IN THE EARLY PALEOZOIC}

Cn the basis of the data of the Piltene, Remte, Blidene, Sturi and Adze borings, the main lines of the geological structure of western Latvia and the development of this region in the Cambrian, Ordovician and Silurian periods are presented. During the Valdaian and Early Baltican times, sedimentation was effected merely in the northern part of the given region (fig. $1 a, \sigma$ ), whereas the southern part represented continental land. In the Late Baltican (fig. 18) and Tiskrean (fig. 12) time, the epicontinental sea transgressed upon all of the territory of western Latvia. During the Tremadocian (fig. 2a), sedimentation was limited but to the narrow depression in the area of the contemporary Liepaja-Jelgava wall, whereas during the Ontikan time (fig. 26), on the same area more clayey and thicker sediments were deposited. During the Middle Ordovician epoch (fig. 26, 2) uniform conditions prevailed throughout western Latvia, but in the Late Ordovician (fig. $22, e$ ) in the north part more shallow-water and thinner deposits were accumulated. In the Llandoverian (fig. $3 a$ ) sedimentation was influenced by the northern Riga depression, whose existence became particularly apparent in the Wenlockian (fig. 36). At the same time, the uplift of the Liepaja-Jelgava wall was begun, which probably resulted in a partial absence of Ludlowian sediments (fig. 36,2 ) in this area as well. In fig. 4 the development of the meridional section of western Latvia is presented ( $a$ - end of the Cambrian, $\sigma$ - end of the Wenlockian, $b$ - end of the Early Ludlowian, 2- beginning of the Quaternary). 